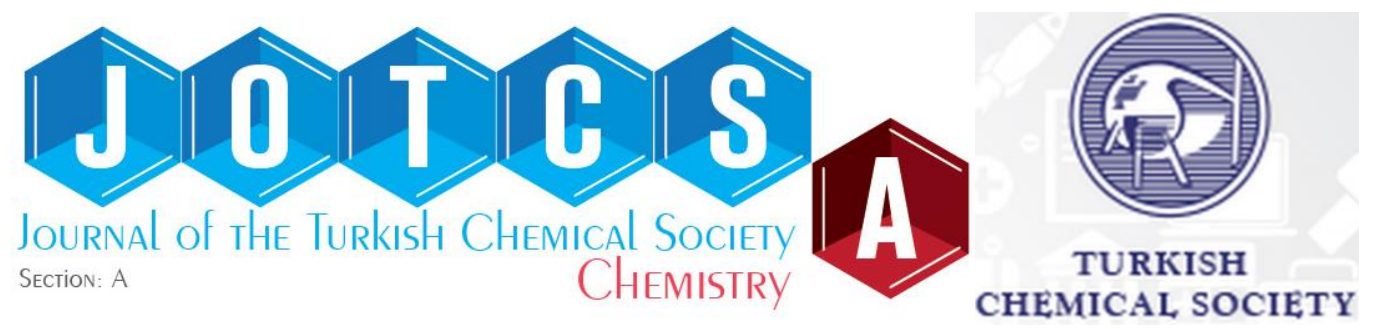

\title{
Synthesis of New Medium- and Large- Sized Racemic and Chiral Lactones
}

\author{
Hasniye Yaşa ${ }^{1 *}$ and Ayşe Sergüzel Yusufoğlu ${ }^{1}$ \\ ${ }^{1}$ Istanbul University, Faculty of Engineering, Department of Chemistry, 34320 Avcllar, \\ İstanbul, Turkey
}

\begin{abstract}
Successive reaction of long chain $\omega-1, \omega-2, \omega-4$ and $\omega-5$ hydroxycarboxylic acids 1a1e with a cyanuric chloride (CC) and triethylamine afforded the corresponding racemic lactones $\mathbf{2 a - 2 e}$ in high yields. Optically pure $R$ lactones $\mathbf{4 a - 4 e}$ were synthesized stereoselectively by porcine pancreas lipase-catalyzed resolution of racemic $\mathbf{2 a - 2 e}$. The resolution conditions were investigated, determined and optical rotations were measured. The mentioned chiral lactones were synthesized by this method for the first time. The obtained racemic and chiral lactones were analyzed by NMR, IR, Mass, optical rotation, and elemental analysis.
\end{abstract}

Keywords: Synthesis, medium and large ring, lactone, enzymatic resolution

Submitted: . Accepted: . (to be assigned)

Cite this: Yasa H., Yusufoglu S. Synthesis of New Medium- and Large- Sized Racemic and Chiral Lactones. JOTCSA. 2018;5(2): 539-50.

DOI: http://dx.doi.org/10.18596/jotcsa.372628.

* Corresponding author. E-mail: hasniye@istanbul.edu.tr 


\section{INTRODUCTION}

Racemic and chiral lactones are commonly found in natural products as a series of pheromones and medical compounds (1-9). They are used also as intermediates for the synthesis of biological substances and natural products (10) due to their biological activities. There are many types of lactones and among them alkyl substituted lactones have gained a lot of interest from the synthetic and medicinal chemists $(11,12)$. Short chain alkyl lactones are essential and significant aromatic compounds in beverages and food.

Enzymes as biocatalysts find significant usage for preparing enantiomerically pure compounds (13). Lipases (triacylglycerol hydrolases, EC 3.1.1.3) are the most commonly used enzymes. They are not only cheap and easy to deliver but also are highly stable and have high enantioselectivity in synthesis.

Various synthetic procedures have been declared in the literature for the preparation of racemic and enantiomerically pure medium and large- ring sized lactones. Several methods using reagents like DCC (14), 2,4,6-trichlorobenzoyl chloride (15), 2,2'-dipyridyl disulfide $/ \mathrm{Ph}_{3} \mathrm{P}$ (16), 1-methyl-2-chloropyridinium iodide / Et $3 \mathrm{~N}$ (17), 2-Me-6- $\mathrm{NO}_{2}$-benzoic anhydride $(18,19)$ and cyanuric chloride (20) have been known for the preparation of the lactones from their corresponding hydroxy acids.

Cyanuric chloride method was chosen in this study, because it is an economical and commercially available reagent. This method has been applied for the synthesis of isoambrettolide (20), exaltolide (21), phorocantholide $(21,22)$, pentadecanolide (22) and patutolide (23). According to the literature survey, the synthesized racemic lactones $2 \mathbf{a}-\mathbf{2 e}$ have not yet been synthesized by cyanuric chloride method. The obtained $R$ - lactones $\mathbf{4 a - 4 e}$ were synthesized by hydrolysis of porcine pancreatic lipase by the first time in this work.

Racemic forms of 12-tetradecanolide (2c) and 14-hexadecanolide (2e) were obtained before differently from the used method in this study (24). There is no record available about their enantiomeric forms $\mathbf{4 c}$ and $\mathbf{4 e}$. Information on racemic and chiral 9-tetradecanolide (2a) and 13-tetradecanolide (2d) is accessible (25-29), but the procedures are not the same. Racemic forms of $\mathbf{2 a}, \mathbf{2} \mathbf{c}, \mathbf{2} \mathbf{d}$ and $\mathbf{2 e}$ were found in the literature but the methods are dissimilar. Chiral 4a, 4c, 4d and 4e were known compounds but their preparation methods are not similar. Racemic 10 tetradecanolide ( $\mathbf{2 b}$ ) and chiral (4b) are original compounds in this study.

These synthesized racemic and chiral lactones can be used in perfumery, medicine, and chemistry as ionic liquids and chromatographic separators due to their ring size. In previous studies, lactones and their derivatives were used as elastase inhibitors $(30,31)$, but this 
inhibition was carried out there only with small ring lactones. In the future, these mentioned racemic and chiral lactones $\mathbf{2 a - 2 e}, \mathbf{4 a - 4 e}$ will be examined for their inhibition of different enzymes especially for their elastase activity, which plays an important and protective role against diseases of lung, arteries, skin, and ligaments.

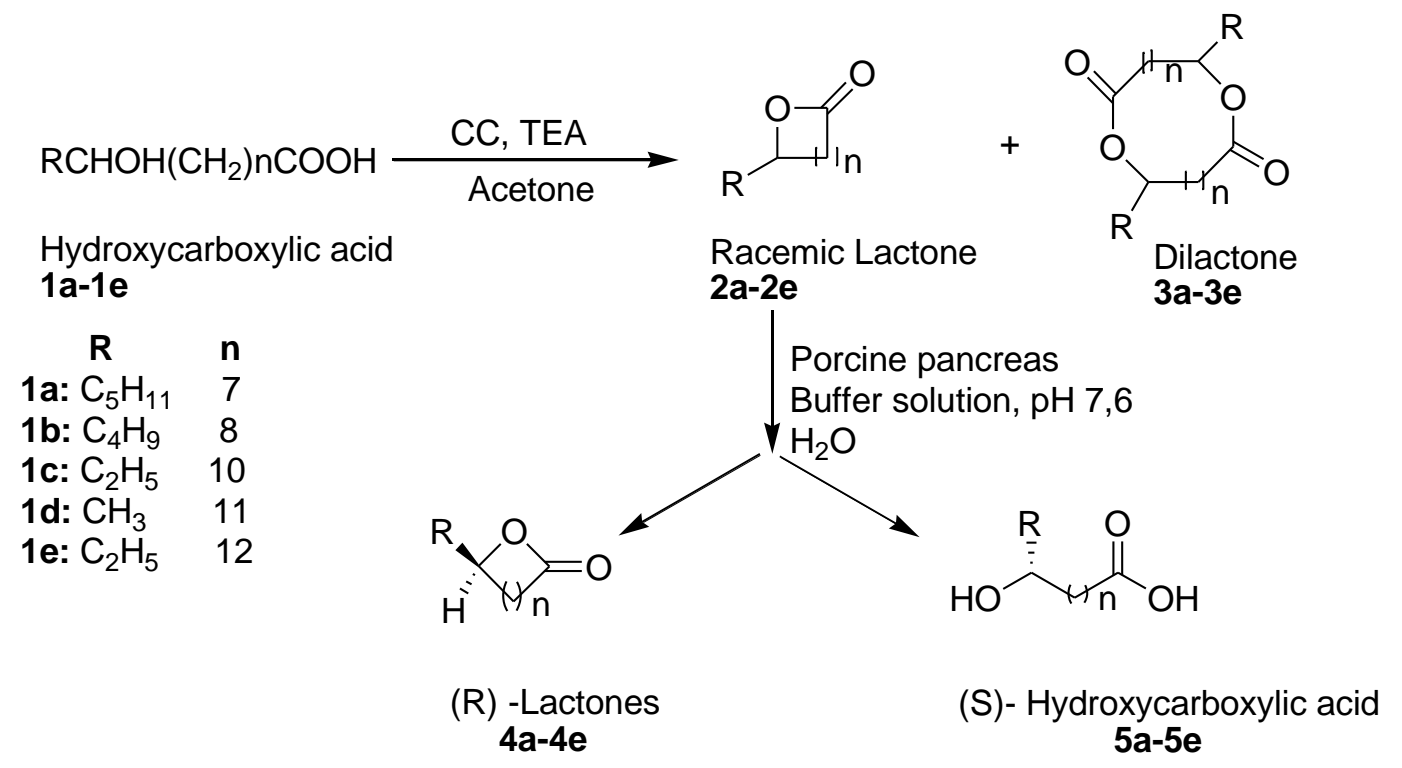

Scheme 1. Synthesis of medium and large sized racemic and enantiomeric lactones.

\section{EXPERIMENTAL SECTION}

\section{General}

All reagents were purchased from commercial products and were used without further purification. Acetone and triethylamine were dried with $\mathrm{CaCl}_{2}$. The reactions were followed up with TLC plate (Merck 60 F-254). Column chromatography was performed on silica gel 60 (70230 mesh). ${ }^{1} \mathrm{H}-\mathrm{NMR}$ and ${ }^{13} \mathrm{C}-\mathrm{NMR}$ spectra were moderated in $\mathrm{CDCl}_{3}$ and booked on a Varian (400 MHz). Mass spectra (ESI) were recorded on a Thermo Finnigan Spectrometer. Infrared (IR) spectra were booked on a Mattson 1000 series spectrometer as thin films between $\mathrm{NaCl}$ plates. Optical rotations were measured on an Optical Activity AA-55 digital polarimeter.

\section{General method for the synthesis of chiral lactones}

Enzymatic hydrolysis of substrate / PPL of varying the weight ratio and reaction time (entries 1-4) were applied by the conditions described in Table 3. Several suspension amounts of the racemic lactones (2a-e, $100 \mathrm{mg}$ ) were incubated at $\mathrm{pH} 7.6$ (citric acid/ $\mathrm{Na}_{2} \mathrm{HPO}_{4}$ buffer solution $0.02 \mathrm{M}$ ) and $36^{\circ} \mathrm{C}$ in water. The obtained suspension was stirred in an ultrasonic bath. Then, the reaction was finished with the supplementation of $\mathrm{CH}_{2} \mathrm{Cl}_{2}$ (32) at the time shown in the Table III. The organic layer was separated, washed with distilled water and dried with $\mathrm{Na}_{2} \mathrm{SO}_{4}$. The solvent was removed in vacuo. To offer a mixture (R)-4a-e and (S)-5a-e that was separated with column chromatography (silica gel, hexane/ethyl acetate $=4 / 1 \mathrm{v}: \mathrm{v}$ ) to give 
lactones in good yield. The obtained lactones that are not UV-active can be seen by the TLC plate dipped into a $5 \% \mathrm{H}_{2} \mathrm{SO}_{4}$ solution and then heated.

(9R)-(-)-9-tetradecanolide (4a). $58 \%$ yield $(58 \mathrm{mg})$ as a colorless oil, hexane/ethyl acetate $=4 / 1 \mathrm{R}_{\mathrm{f}}: 0.44 .[\alpha]_{D}^{20}=-28^{\circ}$ (c 0.45, $\mathrm{CHCl}_{3}$ ). FTFTIR (neat): $\mathrm{V}_{\max }=2946,2865,1727$, $1188 \mathrm{~cm}^{-1} .{ }^{1} \mathrm{H}-\mathrm{NMR}\left(400 \mathrm{MHz}, \mathrm{CDCl}_{3}\right): \delta=0.84(\mathrm{t}, J=7.3 \mathrm{~Hz}, 3 \mathrm{H}), 0.98-1.1(\mathrm{~m}, 2 \mathrm{H}), 1.2-1.33$ $(\mathrm{m}, 14 \mathrm{H}), 1.46-1.7(\mathrm{~m}, 4 \mathrm{H}), 2.27$ (ddd, $J=14.16,7.8$ and $5.3 \mathrm{~Hz}, 2 \mathrm{H}), 4.82(\mathrm{~m}, 1 \mathrm{H}) \mathrm{ppm}$. ${ }^{13} \mathrm{C}-\mathrm{NMR}\left(125 \mathrm{MHz}, \mathrm{CDCl}_{3}\right): \delta=9.9,22.2,24.6,26.4,28.1,28.4,28.6,28.7,28.9,32.6$, $34.00,40.2,74.00,172.75$ ppm. MS (EI): m/e $227[\mathrm{M}+1]^{+}$. Anal. Calc. for $\mathrm{C}_{14} \mathrm{H}_{26} \mathrm{O}_{2}$ : C, 74.29; $\mathrm{H}, 11.58$. Found: $C, 74.20 ; \mathrm{H}, 11.52$.

(10R)-(-)-10-tetradecanolide (4b). 54\% yield $(54 \mathrm{mg})$ as a colorless oil, hexane/ethyl acetate $=4 / 1 \mathrm{Rf}_{\mathrm{f}}: 0.41[\alpha]_{D}^{20}=-25^{\circ}\left(\mathrm{c} 0.45, \mathrm{CHCl}_{3}\right)$. FTIR (neat): $\mathrm{v}_{\max }=2919,2865,1730,1212$ $\mathrm{cm}^{-1} .{ }^{1} \mathrm{H}-\mathrm{NMR}\left(400 \mathrm{MHz}, \mathrm{CDCl}_{3}\right): \delta=0.89(\mathrm{t}, J=6.8 \mathrm{~Hz}, 3 \mathrm{H}), 1.18-1.32(\mathrm{~m}, 14 \mathrm{H}), 1.42-1.7(\mathrm{~m}$, $6 \mathrm{H}), 2.25(\mathrm{~m}, 2 \mathrm{H}), 4.88$ (dddd, $J=7.8,6.8,6.35$ and $3.9 \mathrm{~Hz}, 1 \mathrm{H}) \mathrm{ppm} .{ }^{13} \mathrm{C}-\mathrm{NMR}(125 \mathrm{MHz}$, $\left.\mathrm{CDCl}_{3}\right): \delta=12.95,21.59,24.12,24.28,26.53,27.66,27.97,28.11,28.30,32.85,33.69$, 34.12, 76.11, 175.26 ppm. MS (EI): m/e $227[M+1]^{+}$. Anal. Calc. for $\mathrm{C}_{14} \mathrm{H}_{26} \mathrm{O}_{2}: \mathrm{C}, 74.29 ; \mathrm{H}$, 11.58. Found: $C, 74.25 ; \mathrm{H}, 11.52$.

(12R)-(-)-12-tetradecanolide (4c). $50 \%$ yield $(50 \mathrm{mg})$ as a colorless oil, hexane/ethyl acetate $=4 / 1 \mathrm{R}_{\mathrm{f}}: 0.32 .[\alpha]_{D}^{20}=-26^{\circ}\left(\mathrm{c} 0.45, \mathrm{CHCl}_{3}\right.$ ). FTFTIR (neat): $\mathrm{V}_{\max }=2920,2865,1728$, $1202 \mathrm{~cm}^{-1} .{ }^{1} \mathrm{H}-\mathrm{NMR}\left(400 \mathrm{MHz}, \mathrm{CDCl}_{3}\right): \delta=0.84(\mathrm{t}, J=7.3 \mathrm{~Hz}, 3 \mathrm{H}), 0.98-1.1(\mathrm{~m}, 2 \mathrm{H}), 1.2-1.33$ $(\mathrm{m}, 14 \mathrm{H}), 1.46-1.7(\mathrm{~m}, 4 \mathrm{H}), 2.27$ (ddd, $J=14.16,7.8$ and $5.3 \mathrm{~Hz}, 2 \mathrm{H}), 4.82(\mathrm{~m}, 1 \mathrm{H}) \mathrm{ppm}$. ${ }^{13} \mathrm{C}-\mathrm{NMR}\left(125 \mathrm{MHz}, \mathrm{CDCl}_{3}\right): \delta=9.99,24.2,24.6,26.4,28.1,28.4,28.6,28.7,28.9,32.6$, $34.00,40.2,74.00,172.75$ ppm. MS (EI): m/e $227[\mathrm{M}+1]^{+}$. Anal. Calc. for $\mathrm{C}_{16} \mathrm{H}_{26} \mathrm{O}_{2}: \mathrm{C}, 74.29$; $H, 11.58$. Found: $C, 74.27 ; H, 11.56$.

(13R)-(-)-13-tetradecanolide (4d). $60 \%$ yield $(60 \mathrm{mg})$ as a colorless oil, hexane/ethyl acetate $=4 / 1 \mathrm{R}_{\mathrm{f}}: 0.27 .[\alpha]_{D}^{20}=-33^{\circ}\left(\mathrm{c} 0.45, \mathrm{CHCl}_{3}\right.$ ). FTIR (neat): $\mathrm{V}_{\max }=2919,2865,1728,1266$, $1104 \mathrm{~cm}^{-1}$. ${ }^{1} \mathrm{H}-\mathrm{NMR}\left(400 \mathrm{MHz}, \mathrm{CDCl}_{3}\right): \delta=1.19(\mathrm{~d}, J=6.25 \mathrm{~Hz}, 3 \mathrm{H}), 1.22-1.51(\mathrm{~m}, 16 \mathrm{H}), 1.54-$ $1.64(\mathrm{~m}, 2 \mathrm{H}), 1.66-1.72(\mathrm{~m}, 1 \mathrm{H}), 1.94-2.05(\mathrm{~m} .1 \mathrm{H}), 2.26$ (ddd, J=15.09, 7.5 and $4.3 \mathrm{~Hz}$, $1 \mathrm{H}$ ), 2.34 (ddd, $J=15.09,7.4$ and $4.3 \mathrm{~Hz}, 1 \mathrm{H}$ ), 4.9 (qdd, $J=6.76,12.25$ and $6.25 \mathrm{~Hz}, 1 \mathrm{H}$ ) ppm. ${ }^{13} \mathrm{C}-\mathrm{NMR}\left(125 \mathrm{MHz}, \mathrm{CDCl}_{3}\right): \delta=14.49,23.73,25.23,25.99,29.38,29.49$ 29.78, 29.87, $34.65,39.63,39.65,60.39,68.44,174.17$ ppm. MS (EI): m/e $227[M+1]^{+}$. Anal. Calc. for $\mathrm{C}_{14} \mathrm{H}_{26} \mathrm{O}_{2}$ : C, 74.29; $\mathrm{H}, 11.58$. Found: $\mathrm{C}, 74.26 ; \mathrm{H}, 11.52$.

(14R)-(-)-14-hexadecanolide (4e). $56 \%$ yield $(56 \mathrm{mg})$ as a colorless oil, hexane/ethyl acetate $=4 / 1 \mathrm{R}_{\mathrm{f}}: 0.25 .[\alpha]_{D}^{20}=-44^{\circ}\left(\mathrm{c} 0.45, \mathrm{CHCl}_{3}\right)$. FTIR (neat): $\mathrm{v}_{\max }=2919,2865,173271185$ $\mathrm{cm}^{-1} .{ }^{1} \mathrm{H}-\mathrm{NMR}\left(400 \mathrm{MHz}, \mathrm{CDCl}_{3}\right): \delta=0.86(\mathrm{t}, J=7.3 \mathrm{~Hz}, 3 \mathrm{H}), 1.1(\mathrm{~m}, 2 \mathrm{H}), 1.2-1.34(\mathrm{~m}, 16 \mathrm{H})$, 
1.48-1.62 (m, 6H), 2.28 (ddd, $J=14.65,7.8$ and $4.3 \mathrm{~Hz}, 2 \mathrm{H}), 4.8(\mathrm{~m}, 1 \mathrm{H})$ ppm. ${ }^{13} \mathrm{C}-\mathrm{NMR}(125$ $\left.\mathrm{MHz}_{2} \mathrm{CDCl}_{3}\right): \delta=8.7,24.34,24.42,25.26,25.95,26.24,26.76,27.95,28.12,28.54,30.48$, $32.62,33.74,37.10,74.15,175.26$ ppm. MS (EI): m/e $254[\mathrm{M}]^{+}$. Anal. Calc. for $\mathrm{C}_{16} \mathrm{H}_{30} \mathrm{O}_{2}: \mathrm{C}$, 75.53; $H, 11.89$. Found: $C, 75.48 ; H, 11.85$.

\section{General method for the synthesis of racemic lactones}

0.01 mole of hydroxy acid was placed in a two-necked reaction flask equipped with a magnetic stirrer. It was dissolved in $100 \mathrm{~mL}$ of acetone with heating (if necessary) and cooled to room temperature. 0.01 mole of cyanuric chloride and 0.02 mole of triethylamine was added until a clear solution was obtained. After about 20 minutes, a precipitate comes out and gradually increases. The obtained precipitate was filtered. The filtrate was diluted with water and extracted with chloroform. The organic phase was washed with $10 \% \mathrm{Na}_{2} \mathrm{CO}_{3}$ and water, dried by $\mathrm{Na}_{2} \mathrm{SO}_{4}$, and evaporated. The colorless oil was purified by flash chromatography to give lactones in excellent yield (20).

9-tetradecanolide (2a). This compound is a colorless oil and has $64 \%$ yield. The spectroscopic data were identical to that of enantiomeric $\mathbf{4 a}$.

10 -tetradecanolide (2b). This compound is a colorless oil and has $73 \%$ yield. The spectroscopic data were identical to that of enantiomeric $\mathbf{4 b}$.

12-tetradecanolide (2c). This compound is a colorless oil and has $75 \%$ yield. The spectroscopic data were identical to that of enantiomeric $\mathbf{4 c}$.

13-tetradecanolide (2d). This compound is a colorless oil and has $78 \%$ yield. The spectroscopic data were identical to that of enantiomeric $\mathbf{4 d}$.

14-hexadecanolide (2e). This compound is a colorless oil and has $54 \%$ yield. The spectroscopic data were identical to that of enantiomeric $\mathbf{4 e}$.

\section{RESULTS AND DISCUSSION}

The starting substances 9-, 10-, 12- hydroxytetradecanoic acids and 14-hydroxyhexadecanoic acid (1a-1e) were synthesized by $\mathrm{NaBH}_{4}$ reduction and hydrolysis of their corresponding keto esters, which were prepared by Blaise condensation method (33) and 13-hydroxytetradecanoic acid was obtained according to the acetoacetic ester method with good yields (Table 1) (34, 35). 
Table 1: The results of synthesized racemic hydroxy acids $\left(\mathrm{RHOHC}\left(\mathrm{CH}_{2}\right)_{n} \mathrm{COOH}(\mathbf{1 a - 1 e})\right.$.

\begin{tabular}{lllllll}
\hline Entry & $\mathrm{R}$ & $\mathrm{n}$ & $\begin{array}{l}\text { Hydroxy } \\
\text { Acids }\end{array}$ & $\mathrm{mp}\left({ }^{\circ} \mathrm{C}\right)$ & $n_{D}^{80}$ & $\begin{array}{l}\text { Yield } \\
\%\end{array}$ \\
\hline 1 & $\mathrm{C}_{5} \mathrm{H}_{11}$ & 7 & $\mathbf{1 a}$ & $69-70$ & 1.4432 & 80 \\
2 & $\mathrm{C}_{4} \mathrm{H}_{9}$ & 8 & $\mathbf{1 b}$ & $57-58$ & 1.4410 & 85 \\
3 & $\mathrm{C}_{2} \mathrm{H}_{5}$ & 10 & $\mathbf{1 C}$ & $58-59$ & 1.4390 & 90 \\
4 & $\mathrm{CH}_{3}$ & 11 & $\mathbf{1 d}$ & $58-59$ & 1.4405 & 90 \\
5 & $\mathrm{C}_{2} \mathrm{H}_{5}$ & 12 & $\mathbf{1 e}$ & $59-60$ & 1.4420 & 95 \\
\hline
\end{tabular}

* Isolated yield.

The synthesized hydroxycarboxylic acids were converted to their corresponding racemic lactones by cyanuric chloride method (Scheme 1, Table 2).

The best lactonization yield was found for the molar fraction of hydroxy acid:CC:TEA as 1:1:2. Increased ring size is reduced the efficiency of lactonization yield (Table 2, entries 13-15). The size of alkyl substitution has not played an important role in the lactonization yield. Various acetone amounts were tried to increase of the lactonization reaction yield, the optimal amount was found to be $10 \mathrm{~mL}$ (Table 2). The lactonization was carried out at room temperature until the disappearance of hydroxy acid. The reaction was also examined at refluxing temperature for the reduced reaction time, but dilactone was obtained as a by-product in this reaction. Therefore, lactonization was preferred at room temperature. (Table 2). 
Table 2: Synthesis of medium- and large-sized racemic lactones.

$\begin{array}{lllll}\text { Acetone } & \text { Yield (\%) } \\ (\mathrm{mL}) & & \\ \text { [b] }\end{array}$

[a] Conditions, hydroxycarboxylic acids $1 \mathrm{mmol}$, cyanuric chloride (CC) $1 \mathrm{mmol}$, triethylamine (TEA) $2 \mathrm{mmol}, \mathrm{t}=$ room temperature, reaction time: $24 \mathrm{~h}$. [b] Isolated yield. [c] Dilactone yield.

\section{Choice of lipase enzyme to be used}

According to the literature survey made, porcine pancreas lipase was considered to be proper in the enzymes for enzymatic hydrolysis. Moreover, it is advantageous that this enzyme is much more economical than other enzymes. It hydrolyzed the $S$ enantiomers making the formations of $(R)-\mathbf{4 a - 4 e}$ by enzyme PPL chosen in this study. The best conditions for synthesis of $(R)-4 a-4 e$ in good yields are given in Table 4. 
Table 3: Enantioselective resolution of $\mathbf{2 a - 2 e}$ by PPL.

\begin{tabular}{|c|c|c|c|c|c|c|c|c|c|c|}
\hline \multirow[t]{2}{*}{ Entry } & \multicolumn{2}{|c|}{$(R)-4 a$} & \multicolumn{2}{|c|}{$(R)-4 \mathbf{b}$} & \multicolumn{2}{|c|}{$(R)-4 \mathrm{c}$} & \multicolumn{2}{|c|}{$(R)-4 d$} & \multicolumn{2}{|c|}{$(R)-4 \mathrm{e}$} \\
\hline & {$[\alpha]_{D}^{20}$} & $\begin{array}{l}\text { Yielda } \\
\%\end{array}$ & {$[\alpha]_{D}^{20}$} & $\begin{array}{l}\text { Yielda } \\
\%\end{array}$ & {$[\alpha]_{D}^{20}$} & $\begin{array}{l}\text { Yielda } \\
\%\end{array}$ & {$[\alpha]_{D}^{20}$} & $\begin{array}{l}\text { Yielda }^{a} \\
\%\end{array}$ & {$[\alpha]_{D}^{20}$} & $\begin{array}{l}\text { Yield } \\
\%\end{array}$ \\
\hline 1 & $-27^{\circ}$ & 45 & $-22^{\circ}$ & 35 & $-25^{\circ}$ & 38 & $-30^{\circ}$ & 42 & $-39^{\circ}$ & 41 \\
\hline 2 & $-28^{\circ}$ & 58 & $-25^{\circ}$ & 54 & $-26^{\circ}$ & 50 & $-33^{\circ}$ & 60 & $-44^{\circ}$ & 56 \\
\hline 3 & $-20^{\circ}$ & 20 & $-21^{\circ}$ & 25 & $-23^{\circ}$ & 30 & $-29^{\circ}$ & 34 & $-36^{\circ}$ & 36 \\
\hline 4 & $-19^{\circ}$ & 10 & $-20^{\circ}$ & 20 & $-24^{\circ}$ & 25 & $-28^{\circ}$ & 30 & $-31^{\circ}$ & 32 \\
\hline
\end{tabular}

a isolated yields

Table 4: PPL-catalyzed hydrolysis of racemic $\mathbf{2 a - 2 e}$ with different ratios of substrate/PPL.

\begin{tabular}{lllll}
\hline Entry & $\begin{array}{l}\text { Substrate }^{\mathrm{a}}(\mathrm{mg}) / \\
\text { Suspension }^{\mathrm{b}}\left(\mathrm{cm}^{3}\right)\end{array}$ & $\begin{array}{l}\text { PPL }(\mathrm{mg}) / \\
\text { Suspension }\left(\mathrm{cm}^{3}\right)\end{array}$ & Substrate/PPL & Reaction time $(\mathrm{h})$ \\
\hline 1 & $1,000: 56$ & $1,000 / 56$ & $1: 1$ & 7 \\
2 & $1,000: 28$ & $500 / 28$ & $2: 1$ & 7 \\
3 & $1,000: 18.67$ & $333: 18.67$ & $3: 1$ & 7 \\
4 & $1,000: 9.33$ & $166.6: 9.33$ & $6: 1$ & 7 \\
\hline
\end{tabular}

a Racemic 2a-e $(1.000 \mathrm{mg})$ was taken in these procedures.

b $1 \mathrm{~cm}^{3}$ of suspension, produced from $1 \mathrm{~g}$ of lipase and $15 \mathrm{~cm}^{3}$ of water, hydrolyzed $50 \mathrm{mg}$ of trimyristine (36)

The best resolution for $\mathbf{2 a - 2 e}$ was entry 3. (R)-4a-4e were synthesized with good yields after $7 \mathrm{~h}$ incubation with a substrate/PPL weight ratio 2:1 (Entry 2, Table 4). There are a lot of studies mentioned about chiral lactones that clearly refined by $\mathrm{R}$ configuration due to negative optical rotation. Therefore, the synthesized chiral lactones were attributed to be of $R$ configuration according to the measured optical rotations. The configurations of the chiral lactones with negative sign were defined in the literature as $(R)(25-29)$.

Therefore, enantioseparation studies were also tried in this work and the enantiospecificity of the resolution was determined after purification of the $(R)-\mathbf{4 a - 4 e}$ by column chromatography. For determination of enantiomeric enrichment (\% ee), Cyclodex $\beta-25 \mathrm{~m}$ column chiral capillary GC column was used for gas chromatographic separation. Different GC separation conditions were tried, but resolution of $(R)$ and $(S)$ enantiomers of the obtained lactones were not succeeded. Configuration of the synthesized lactones were assigned due to the optical rotation degrees in the literature (24-28), where lactones with negative optical rotations were defined as $(R)$. Therefore the synthesized lactones in this study were attributed to be of $\mathrm{R}$ configuration (Table 3). Synthesized racemic and chiral lactones were obtained for the first time by the method used in this study. 


\section{CONCLUSION}

In this work, medium- and large-ring racemic $\mathbf{2 a - 2 e}$ and chiral lactones $\mathbf{4 a - 4 e}$ were synthesized in good yields. The enzymatic resolution of the synthesized racemic lactones was carried out under mild conditions. The described processes in this study are cheap and environmentally friendly. The purification of the lactones were achieved by column chromatography. The synthesized racemic and chiral lactones $\mathbf{2 a - 2 e}$ and $\mathbf{4 a - 4 e}$ mentioned were analyzed by FTIR, ${ }^{1} \mathrm{H}-\mathrm{NMR},{ }^{13} \mathrm{C}-\mathrm{NMR}$, Mass spectra, optical rotation, and $\mathrm{C}, \mathrm{H}$ analysis. The synthesized racemic and chiral lactones will be examined in the future for their usefulness in food, pharmacy and cosmetic industries. They will be investigated for their inhibition effect of several enzyme types.

\section{ACKNOWLEDGEMENTS}

This work was supported by Scientific Research Projects Coordination Unit of Istanbul University. Project number: T-1132/18062001 and YADOP-5161.

\section{REFERENCES}

1. Siegel SM. Inhibitory activity of the phenolic glucoside psilotin and its several by gibberellic acid and thiols. Phytochem. 1976; 15: 566-7.

2. Ohloff G. Recent developments in the field of naturally occurring aroma components. Prog. Chem. Org. Nat. Prod. 1978; 35: 431-527.

3. Davies-Coleman MT, Rivett DEA. Naturally occurring 6-substituted 5,6-dihydro-a-pyrones. Chem. Org. Nat. 1989; 55: 1-35.

4. Fukusaki E, Senda S, Nakazono Y, Omata T. Lipase-catalyzed kinetic resolution of methyl 4hydroxy-5-tetradecynoate and its application to a facile synthesis of Japanese beetle pheromeno. Tetrahedron 1991; 47: 6223-30.

5. Mori K. Synthesis of optically active pheromenos. Tetrahedron 1989; 45: 3233-98.

6. Fujita $\mathrm{T}$, Nishimura $\mathrm{H}$, Kaburagi $\mathrm{K}$, Mizutani J. Plant-growth-inhibiting a-pyrones from Alpina spiciosa. Phytochem. 1994; 36: 23-7.

7. Nyandat E, Rwekika E, Galeffi C, Palazzino G, Nicoletti M. Olinioside,5-(4'-O- $\beta$-Dglucopyranosyl)-caffeoyloxy-5,6-dihydro-4-methyl-(2H)-pyran-2-one from Olinia usambarensis. Phytochem. 1993; 33: 1493-6.

8. Adrianaivoravelona JO, Sahpaz S, Terreaux C, Hostettmann K, Stoeckli-Evans H, Rasolondramanitra H. Two 6-substituted 5,6-dihydro-a-pyrones from Ravensara anisata. Phytochem. 1999; 52: 265-9.

9. Pereda-Miranda R, Garcia M, Delgado G. Structure and stereochemistry of four a-pytones from Hyptis oblongifolia. Phytochem., 1990; 29: 2971-4. 
10. Nicolaou KC, Rodrigues RM, Mitchell HJ, Suzuki H, Fylaktakidou KC, Baudoin O, van Delft FL. Total synthesis of everninimicin $13,384-1$, part 1 : Retrosynthetic analysis of the $A 1 B(A) C$ fragment. Chem. Eur. J, 2000; 6: 3095-115.

11. Jodynis-Liebert J, Murias M, Bloszyk E. Effect of sesquiterpene lactones and antioxidant enzymes and some drug-metabolizing enzymes in rat liver and kidney. Planta Med. 2009; 66: 199-205.

12. Drewes SE, Schlapelo BM, Horn MM, Scott-Shaw V, Sandor O. 5,6-Dihydro-a-pyrones and two bicyclic tetrahydro-a-pyrone derivatives from Cryptocarya latifolia. Phytochem. 1995; 38: 1427-30.

13. (a) Drauz K, Waldmann H. Enzyme Catalysis in Organic Synthesis. VCH: Weinheim, 1995.

(b) Bornscheuer UT, Kazlauskas RJ. Hydrolases in Organic Synthesis, Wiley- VCH: Weinheim, 1999.

14. Boden EP, Keck GE. Proton-transfer steps in Steglich esterification: a very practical new method for macrolactonization, J.Org.Chem. 1985; 50: 2394.

15. Inanaga J, Hirata K, Saeki L, Katsuki T, Yamaguchi M. A rapid esterification by mixed anhydride and its application to large-ring lactonization. Bull. Chem. Soc. Jpn. 1979; 52: 1989.

16. Corey EJ, Nicolaou KC. Efficient and mild lactonization method for the synthesis of macrolides. J.Am.Chem.Soc. 1974; 96: 5614-6.

17. Mukaiyama T, Usui M, Saigo K. The facile synthesis of lactones. Chem. Lett. 1976; 5: 4950.

18. Shiina I, Kubota M, Ibuka R. A novel and efficient macrolactonization of $\omega$ hydroxycarboxylic acids using 2-methyl-6-nitrobenzoic anhydride (MNBA). Tetrahedron Lett. 2002; 43: 7535-9.

19. Shiina I, Kubota M, Oshiumi $H$, Hashizume M. An Effective Use of Benzoic Anhydride and Its Derivatives for the Synthesis of Carboxylic Esters and Lactones: A Powerful and Convenient Mixed Anhydride Method Promoted by Basic Catalysts. J.Org.Chem. 2004; 69: 1822-30.

20. Venkataraman K, Wagle DR. Cyanuric chloride, a useful reagent for macrocyclic lactonization. Tetrahedron Lett. 1980; 21: 1893-6.

21. Cossy J, Peten JP. A three step synthesis of exaltolide and phoracantholide I. Tetrahedron Lett. 1986; 27: 2369-70.

22. Cossy J, Pete JP. Synthesis of medium-ring lactones: Application to the synthesis of 15pentadecanolide and phoracantholide I. Bull. Soc. Chim.Fr. 1988; 6: 989-94. CODEN: BSCFAS; ISSN: 0037-8968; French

23. Ayyangar NR, Chanda B, Wakharkar RD, Kasar RA. A short convergent synthesis of Patulolide A. Synth.Commun. 1988; 18: 2103-19.

24. Hinkamp L, Schaefer H, Wippich B, Luftmann H. Regioselective conversion of nonactivated carbon-hydrogen bonds. VI. Selective $\omega$ - to $(\omega-2)$-chlorination of fatty acids via adsorption on alumina. Liebigs Annalen der Chemie 1992; 6: 559-63.

25. Noda Y, Kashin H. Synthesis of Both Enantiomers of Four Different Macrocyclic Lactones. Heterocycles 1998; 48: 5-10. 
26. Stanchev $S$, Hesse M. Synthesis of the enantiomerically enriched macrocyclic lactones $(+)$ (S)- and (-)-(R)-phorocantholide I and (+)-(S)-tetradecan-13-olide. Helv. Chim. Acta 1990; 73: $460-7$.

27. Bestmann H.J, Kellermann W. Synthese der natürlichen R-( - )Enantiomere dreier Galbanum-Harz Macrolide. Synthesis 1994; 12: 1257-61.

28. Kaiser R, Lamparsky $D$. Neue Macrolide und einige sesquiterpen-derivative aus dem Galbanum-Harz. Helv.Chim.Acta. 1978; 61: 2671-80.

29. Bollbuck B, Kraft P, Tochtermann W. Nature-like odorants by stereoselective ring enlargement of cyclohexanone and cyclododecanone. Tetrahedron 1996; 52: 4581-92.

30. Siedle B, Gustavsson L, Johansson S, Murillo R, Castro V, Bohlin V, Merfat I. The effect of sesquiterpene lactones on the release of human neutrophil elastase. Biochem. Pharmacol. 2003; 65: 897-903.

31. Dou D, He G, Li Y, Lai Z, Wei L, Alliston KR, Lushington GH, Eichhorn DM, Groutas WC. Utilization of the 1,2,3,5-thiatriazolidin-3-one 1,1-dioxide scaffold in the design of potential inhibitors of human neutrophil proteinase 3. Bioorg. Med. Chem. 2010; 18: 1093-102.

32. Baspinar Kücük H, Yusufoglu A. Enantioselective synthesis of 3-hydroxytetradecanoic acid and its methyl ester enantiomers as new antioxidants and enzyme inhibitors. Monatsh Chem. 2013; 144: 1087-91.

33. Blaise EE. Blaise Reactions. C.R.Hebd. Seacens Acad. Sci. 1913; 157: 1440

34. Stenhagen SS, Stenhagen E. Synthesis of higher beta keto acids with 9 to 24 carbon atoms. Arkiv Kemi Mineral Geol. A 1945; A20: No:19.

35. Çelik $\mathrm{H}$. Synthesis of monoketo and monohydroxy eicosanoic acids and esters with substituents at odd-numbered (3-13) carbons. J. Serb. Chem. Soc. 2002; 67: 473-80.

36. Yanardağ R, Bapçum A. Chim Acta Turc. 1996; 24: 15. 
